\title{
Wstęp
}

\section{Szukając dialogu}

Trudno byłoby zapewne znaleźć kraje, których historia obfitowałaby w tak wiele zakrętów, barier i nieporozumień w sferze wzajemnych relacji, jak Polska i Rosja. Wiele też jest paradoksów w tych stosunkach: skrajnie odmienne postrzeganie historycznego wpływu tego sąsiedztwa przez oba społeczeństwa (to jest odbieranie go jako czegoś negatywnego i destrukcyjnego bądź przeciwnie, dobroczynnego zależnie od tego, kto nad kim zyskiwał przewagę na przestrzeni dziejów); niechęć do sąsiedniego kraju jako pewnej struktury polityczno-państwowej, przy jednoczesnym zaintrygowaniu oraz często sympatii w indywidualnych kontaktach międzyludzkich; przynależność do tego samego chrześcijańskiego kręgu religijno-kulturowego, a zarazem separacja i nierzadko wrogość w efekcie Wielkiej Schizmy; uderzające podobieństwa, a zarazem oczywiste różnice w zakresie ludzkiej mentalności; niedocenianie lub na odwrót - przecenianie wpływu sąsiada na realność polityczną w regionie środkowo- $\mathrm{i}$ wschodnioeuropejskim.

Efektem jest, rzecz jasna, szczególna trudność wywikłania wzajemnych wpływów i filiacji w sferze kultury (bardzo znaczących, właściwie trudnych do przecenienia) z gęstego kokonu politycznych i społecznych stereotypów oraz efektów świadomej manipulacji. Obraz kultury polskiej w oczach Rosjanki lub Rosjanina skryty jest niewątpliwie w cieniu stojącego na Placu Czerwonym pomnika Kuźmy Minina i Dymitra Pożarskiego, obraz kultury rosyjskiej w oczach Polki lub Polaka - w cieniu popiersia Romualda Traugutta na warszawskiej Cytadeli lub innych tego typu upamiętnień. We wzajemnym zrozumieniu przeszkadza z całą pewnością oczywista różnica skali: o ile Polska - jako kraj przeciętny pod względem różnorako pojmowanego potencjału - wpisała się obecnie w Sojusz Atlantycki i Wspólnotę Europejską (choć nie bez problemów i nie w sposób absolutnie rozstrzygający), 
to Rosja pozostała i w dającej się przewidzieć przyszłości zapewne pozostanie wielonarodowym imperium, mającym znaczny wpływ na światową geopolitykę. Patrząc z perspektywy konieczności zachowania takiego imperium w całości oraz w dobrej kondycji ekonomicznej (zwłaszcza że do klasycznej doktryny imperialnej Rosji należy utrzymywanie własnej, szerokiej strefy wpływów poza granicami ${ }^{\mathrm{I}}$ ), trudno jest rosyjskim instytucjom (kulturalnym, naukowym czy oświatowym) prowadzić choćby częściowo niezależną politykę, wbrew woli ogólnokrajowych decydentów. Niesłabnące napięcie pomiędzy obu państwami (spowodowane przede wszystkim zasadniczo antyzachodnim kursem obecnych władz Rosji, a w dalszej kolejności - niechętną rządzonemu przez Putina imperium polityką polską) powoduje, że również instytucje polskie dalekie są od wykorzystania tych możliwości.

W tej sytuacji trudno jest obu stronom uwolnić wzajemne relacje - także te kulturalne i naukowe - od schematów, w których polityka i związane z nią emocje (często podsycane przez profesjonalnych manipulatorów) łączą się ze schematami kulturowymi i czerpią z nich siłę. Do takich poglądów po stronie rosyjskiej należy choćby stereotyp „niewdzięcznych Polaków”. Jako argumenty na rzecz tej „niewdzięczności” przywołuje się w Rosji na przykład konstytucję cara Aleksandra I dla Królestwa Polskiego i powstanie I8zo roku, pomoc ZSRR w stworzeniu armii polskiej na swoim terenie i wyjście armii generała Władysława Andersa do Iranu, wrogość niepodległościowego podziemia polskiego wobec Armii Czerwonej mimo jej zwycięstwa nad hitlerowskimi Niemcami, powstanie „Solidarności” w odpowiedzi na liberalizację systemu komunistycznego, wstąpienie do NATO jako małoduszną ripostę na wyprowadzenie wojsk radzieckich z Polski ${ }^{2}$. Często zwłaszcza w wieku XIX, przed zaistnieniem „kultury masowej” i profesjonalizacją działań propagandowych - stereotypy takie były budowane przez wybitnych pisarzy, których autorytet wyposażał je w znaczną siłę oddziaływania. Przykładem może być Aleksander Puszkin, który po powstaniu listopadowym

\ swoją odpowiedź na „polskie” wydarzenia sformułował początkowo w poetyckim gatunku ody, napisawszy - dwa lata przed stworzeniem Jeźdźca miedzianego, latem i83I roku - utwory Oszczercom Rosji oraz Rocznica Borodino, następnie wydane wspólnie w formie broszury. [...] Obie te ody zaadresowane były nie tyle do pokonanych już Polaków lub do mieszkańców zwycięskiej Rosji, co do czytelników w Euro-

1 W sprawie aktualności tych tendencji w polityce rosyjskiej zob. np. rozmowę Juliusza Ćwielucha z gen. Mirosławem Różańskim Dlaczego przegramy wojnę z Rosją (Kraków 2018).

2 Zob. A. Lipatow, Rosja i Polska: „domowy spór” Stowian czy przeciwieństwo mentalności?, w: Polacy i Rosjanie: wzajemne zrozumienie i niezrozumienie, red. A. Lipatow, I.O. Szajtanow, Moskwa 2000, s. 19. Oczywiście autor wnikliwie i przekonująco wylicza argumenty, które strona polska przeciwstawia tym krzywdzącym schematom. 
pie, która z zaaferowaniem obserwowała przebieg wydarzeń. [...] Zwracając się do europejskiej opinii publicznej, Puszkin odmawia Europejczykom prawa do zabrania głosu w tej kwestii, nakazując im: „Zamilknijcie, to wewnętrzny spór w słowiańskiej rodzinie”.

W ten sposób poeta wzmocnił schemat postrzegania Polaków, jeśli nie jako „zdrajców Słowiańszczyzny”, to co najmniej bardzo znaczących przeciwników Rosji w „słowiańskiej rodzinie”. Nie ulega wątpliwości, że po drugiej, polskiej stronie barykady tego „domowego sporu Słowian” kluczową rolę odgrywał autorytet Adama Mickiewicza. Pomijając nawet często roztrząsaną kwestię poetyckiego agonu między obydwoma twórcami, nie ulega wątpliwości, że Mickiewiczowskie wzorce postrzegania wschodniego sąsiada (nie tylko rusofobiczne) odegrały - i odgrywają nadal - kluczową rolę w kształtowaniu pewnej tradycji pojmowania Rosji w społeczeństwie polskim. Poza obrazem Petersburga w Ustępie do III części „Dziadów" (wraz z zawartym tam ironicznym opisem mało gustownych, zbudowanych w wielu różnych światowych stylach petersburskich rezydencji, zamkniętych za żelaznymi ogrodzeniami, niczym egzotyczne zwierzęta w klatkach ${ }^{4}$ ), poza gorzkimi i sarkastycznymi słowami pod adresem rosyjskiego samodzierżawia (rozsianymi w tak wielu miejscach Mickiewiczowskiego dzieła, że przywoływanie cytatów mija się z celem) czy poza oskarżeniem systemu rosyjskiej władzy o deptanie ludzkiej godności i lekceważenie wartości życia (przede wszystkim w poemacie Przeglad wojska) w świadomości nawet przeciętnie wyedukowanych Polki lub Polaka powinna pobrzmiewać ocena społeczeństwa rosyjskiego jako duchowo „wciąż niegotowego”, nieposiadającego rodzimej, oddolnej, obywatelskiej tradycji (oprócz oficjalnej historii imperium i jego tryumfów $w^{5}$ ), obraz rosyjskiej ziemi jako „ogromnej pustki” (poza ważnymi dla władzy metropoliami), po której tam i z powrotem, ściśle wytyczonymi szlakami wędrują tylko kolumny wojska, by tłumić kolejne bunty dążących do samostanowienia narodów.

Oczywiście w polskiej pamięci kulturowej trwa również wiersz Mickiewicza Do przyjaciót Moskali, poświęcony przyjaciołom dekabrystom i określający - wbrew pozorom - dość precyzyjnie polskie postulaty wobec Rosji i jej mieszkańców:

3 I.O. Szajtanow, Puszkin i problem polski w kontekście idei historii światowej, w: ibidem, s. 82 (tłum. M. Pąkciński).

4 A. Mickiewicz, Dziadów cz. III Ustęp, https://wolnelektury.pl/media/book/pdf/dziady-dziadow-czesci-iii-ustep.pdf, s. 5 ( $\operatorname{stan}$ z 5 stycznia 2019 r.).

5 Jak pisał Mickiewicz: „Spotykam ludzi - z rozrosłymi barki, /Z piersią szeroką, z otyłymi karki; /Jako zwierzęta i drzewa północy, / Pełni czerstwości i zdrowia, i mocy. / Lecz twarz każdego jest jak ich kraina, / Pusta, otwarta i dzika równina; [...] / Tu oczy ludzi, jak miasta tej ziemi, / Wielkie i czyste - i nigdy zgiełk duszy / Niezwykłym rzutem źrenic nie poruszy: / Nigdy ich długa żałość nie zaciemi; / Z daleka patrząc, wspaniałe, przecudne; / Wszedłszy do środka, - puste i bezludne." (ibidem, s. 3). 
będziemy z Wami rozmawiać jak partnerzy (a także „bracia Słowianie”) i nawiązywać przyjazne kontakty wtedy, gdy staniecie się prawdziwymi demokratami. W tym sensie rzec można, że rudymenty polskiej polityki wobec Rosji aż po dzień dzisiejszy - przynajmniej w sferze ideowo-kulturowej - da się określić mianem Mickiewiczowskich. Niestety, trudno byłoby dziś orzec, że ta polityka jest efektywna jako narzędzie oddziaływania na Rosję i jej społeczeństwo. Powstaje zatem pytanie, czy po prawie dwustu latach różnorodnych historycznych doświadczeń obu stron - które nie nastrajają optymistycznie - takie założenia mogą się utrzymać, a społeczeństwo, którego historyczna droga daleka jest od wzorców zachodniej liberalnej demokracji (zaś należące do niego narody nie mają w swojej własnej historii żadnych epizodów demokratycznych, a tym bardziej liberalnych), można postawić poza marginesem „cywilizowanego" dialogu? ${ }^{6}$ Czy wielokilometrowe korki przy wyjeździe z Moskwy w piątek wieczorem (gdy zaczynają się dni wolne i można wreszcie udać się na daczę) nie są równie czytelnym symptomem jakiegoś innego niż polityczne pojmowania wolności ${ }^{7}$, co Pole Elekcyjne na warszawskiej Woli - owego przywiązania społeczeństwa polskiego do idei wolnych wyborów i politycznej podmiotowości „szlacheckiej braci”?

Szczery dialog Polski z Rosją i jej kulturą stał się dzisiaj możliwy - po wyzwoleniu z miazmatów sztucznej przyjaźni z czasów PRL-u i ZSRR - ale interpretacja wzajemnych relacji bez atmosfery obustronnych pretensji jest chyba jeszcze trudniejsza. O ile bowiem w słusznie minionych czasach wszystkie tradycyjne polskie pretensje wobec imperialnej Rosji można było sklasyfikować jako krytykę caratu, wysuwane zaś względem Rosjan postulaty zmiany ich narodowego charakteru - jako sprzyjanie postępowym lewicowym prądom, które zaowocowały Rewolucją Październikową, to dziś, widziane z zewnątrz i bez sympatii, mogą się one układać w logiczną historię narastania „polskiej histerycznej rusofobii”. Rosjanie nie rozumieją, dlaczego pretensje wobec ich kraju nie ustały z chwilą, gdy Polska odzyskała niepodległość i suwerenność ${ }^{8}$. Niespokojna i podminowana wzajemnymi

6 Rosyjscy nieliberalni publicyści (zwani na Zachodzie prokremlowskimi) często wykorzystują następujący argument: w szeroko rozumianym dyskursie Zachodu Rosja jest marginalizowana, a jej punkt widzenia, postulaty i aspiracje są celowo pomijane lub cenzurowane. W odpowiedzi prokremlowska publicystyka formułuje postulatywną prognozę, w której Stany Zjednoczone i Europa Zachodnia same ulegają stopniowej marginalizacji na rzecz rosnących potęg, takich jak Chiny, Indie, Iran, Wietnam, Brazylia, w których gronie Rosja będzie w stanie wytworzyć (a co najmniej aktywnie współtworzyć, choćby dzięki swej militarnej potędze) nowy wzorzec świata policentrycznego. W domyśle kryje się również przekaz, że w takim policentrycznym świecie wartości demokratyczne (rozumiane w sposób zachodni) przestaną odgrywać istotną rolę.

7 Akcentując związek takiego pojmowania wolności z figurą wielkiej, nieogarnionej przestrzeni oraz podróżą, można byłoby nazwać je nomadycznym.

8 Odpowiedzią rosyjskiej oficjalnej publicystyki jest kolejny bardzo często przywoływany stereotyp - jakoby bezkrytyczna „służalczość” Polski wobec Zachodu. (Argument ten niemal mechanicznie został przeniesiony niedawno również na polityczne elity Ukrainy). 
pretensjami atmosfera tego dialogu (o ile obu stronom udaje się do niego doprowadzić) jest tym bardziej chwiejna, że obecnie w oficjalnym dyskursie rosyjskich mass mediów - i coraz bardziej także w świadomości społecznej - wszystkie etapy rosyjskiej historii (łącznie $\mathrm{z}$ dziejami ZSRR, w tym nawet $\mathrm{z}$ okresem stalinowskim) zbierane są w całość, by tworzyły jedną, wspólną tradycję rosyjskiego imperium, którą można byłoby szanować i czcić.

Co mogą uczynić w takiej sytuacji polska humanistka lub humanista, szczerze zafascynowani kulturą rosyjską i polsko-rosyjskim kulturowym dialogiem, o którego dużym znaczeniu była mowa na wstępie? Bez wątpienia zająć się szczegółowymi tematami z tego bardzo szerokiego zakresu badań, wskazując na wzajemne polsko-rosyjskie filiacje, zapożyczenia, fascynacje, a także spory - pod warunkiem że są twórcze i prowadzą do cennych konkluzji, a nie pozostają jałową wymianą ciosów. Można również skoncentrować uwagę na tematach ważnych $\mathrm{z}$ uniwersalnego punktu widzenia (takich na przykład jak genologia dla literaturoznawcy) i oświetlać je $\mathrm{z}$ dwóch stron, korzystając $\mathrm{z}$ różnorodności kultywowanych w tych krajach metod i tradycji badawczych. W obu tych kierunkach idą Autorzy bieżącego numeru „Napisu”, ich wysiłki zaś przedkładamy pod ocenę Czytelników.

Jedno nie ulega wątpliwości - warto kontynuować naszą polsko-rosyjską wspó1pracę, zwłaszcza w sferze humanistyki. Jeśli bowiem można orzec, że dzisiejsza Rosja nie jest państwem demokratycznym - przynajmniej w zachodnim rozumieniu tego słowa - to z pewnością jest krajem poetyckim, czyli takim, w którym poezja wisi w powietrzu. Jak zwykli mawiać ludzie, którzy jej się z bliska przyjrzeli, Rosja (może wbrew Mickiewiczowi i Norwidowi...?) bez wątpienia ma własną duszę. Polacy podświadomie to czują. 